\title{
FAKTOR-FAKTOR YANG MEMENGARUHI NIAT BELI ULANG SAYURAN MELALUI PLATFORM E-COMMERCE DI JABODETABEK
}

\author{
FACTORS AFFECTING REPURCHASE INTENTION \\ VEGETABLES THROUGH THE E-COMMERCE PLATFORM IN JABODETABEK
}

\author{
Atika Dian Pitaloka*)1, Hartoyo*), Mochammad Mukti Ali**) \\ *) Sekolah Bisnis, IPB University \\ Jl. Pajajaran, Bogor 16151, Indonesia \\ ${ }^{* *}$ Departemen Ekonomi, Fakultas Ekonomi, Universitas Mercu Buana \\ Jl. Raya, University of Mercu Buana Jakarta 11650, Indonesia
}

\begin{abstract}
This study analyzes the factors that influence the buying intention of vegetables through e-commerce platforms in Jabodetabek through the variables of perceived ease of use, perceived usefulness, trust, attitude and satisfaction, formulates managerial implications and marketing strategies to increase consumer repurchase intention. This study involved 153 respondents who were selected by convenience sampling technique. Data were collected through questionnaires distributed online. The analysis used Structural Equation Modeling (SEM) with LISREL. The results showed that perceived ease of use had a significant effect on perceived usefulness, perceived usefulness and trust had a significant effect on attitude, attitude has a significant effect on satisfaction and satisfaction has a significant effect on repurchase intention. Managerial implications that can be carried out by vegetable entrepreneurs in e-commerce to increase repurchase intention are continuing to carry out strategies that can increase consumer trust and satisfaction.
\end{abstract}

Keywords: repurchase intention, satisfaction, technology acceptance model, theory of reasoned action, vegetable e-commerce

\begin{abstract}
Abstrak: Penelitian ini menganalisis berbagai faktor yang memberi pengaruh pada niatan pembelian sayuran dengan platform e-commerce dalam wilayah Jabodetabek melalui variabel persepsi kemudahan penggunaan, persepsi kegunaan, kepercayaan, sikap dan kepuasan, merumuskan implikasi manajerial dan strategi pemasaran untuk meningkatkan niat beli ulang konsumen. Penelitian ini melibatkan 153 responden yang dipilih dengan teknik convenience sampling. Data dikumpulkan melalui kuesioner yang disebarkan secara online. Analisis menggunakan Structural Equation Modeling (SEM) dengan LISREL. Hasil dari kegiatan meneliti menandakan persepsi kemudahan dalam penggunaan membawa pengaruh yang bersignifikan terhadap persepsi kegunaan, persepsi kepercayaan serta kegunaan membawa pengaruh yang bersignifikan terhadap sikap, sikap berpengaruh signifikan terhadap kepuasan dan kepuasan membawa pengaruh yang bersignifikan kepada niatan pembelian ulang. Implikasi manajerial yang dapat dilakukan oleh pengusaha sayuran dalam e-commerce guna melakukan peningkatan niat pembelian ulang yakni dengan terus melaksanakan strategi yang dapat meningkatkan kepercayaan dan kepuasan konsumen.
\end{abstract}

Kata kunci: e-commerce sayuran, kepuasan, model penerimaan teknologi, niat beli ulang, teori tindakan beralasan

\footnotetext{
${ }^{1}$ Corresponding author:

Email: atikadiann@yahoo.com
} 


\section{PENDAHULUAN}

Fenomena pandemi covid-19 pada satu sisi, serta berkembangnya inovasi dan teknologi pada sisi lain, menyebabkan pergeseran perilaku konsumen dari yang sebelumnya melakukan transaksi secara konvensional, kini mulai beralih ke arah pola transaksi digital melalui e-commerce. Pergeseran ini cukup intens terjadi pada produk-produk hortikultura, termasuk komoditas sayur. Mengacu kepada hasilnya dari survei Asosiasi Penyelenggara Jasa Internet Indonesia (APJII, 2020) saat 2019-kuartal II/2020 melakukan pencatatan, total pihak yang menggunakan internet pada negara Indonesia menyentuh angka 196,7 juta jiwa yakni $73,7 \%$ dari total penduduk Indonesia dengan jumlah totalnya 266,91 juta jiwa. Angka ini mengalami peningkatan 25,5 juta yakni $8,9 \%$ daripada saat 2018 . Besarnya jumlah pengguna internet menjadi peluang pasar yang menjanjikan bagi e-commerce.

Hasil survei yang dilakukan oleh Redseer dan diberitakan oleh Katadata.co.id (Katadata, 2020a) menyatakan bahwa ada $51 \%$ responden yang mengakui pertama kalinya mempergunakan aplikasi e-commerce untuk berbelanja ketika PSBB. Hal itu mengakibatkan volume permintaan di e-commerce pun meningkat 5-10 kali dibandingkan saat sebelum pandemi berlangsung. Dilihat dari penjualan melalui e-commerce meningkat US\$ 2,4 miliar, naik $26 \%$ dari rerata bulanan kuartal II-2019. Jumlah transaksi harian pun mengalami peningkatan yang cukup signifikan. Pada kuartal II2019 tercatat sebesar 3,1 juta transaksi dalam satu hari ada peningkatan jadi 4,8 juta transaksi saat April 2019 (Katadata, 2020b). Pandemi Covid-19 mampu memberi peningkatan penjualan industri pertanian melalui daring hampir 400\% (Iprice, 2020). Transaksi belanja produk hortikultura pada e-commerce meningkat 2 hingga 5 kali lipat dibandingkan masa sebelum pandemi (Katadata, 2020b).

Meskipun tren berbelanja produk hortikultura mengalami peningkatan, akan tetapi jumlah konsumen yang telah mencoba berbelanja sayuran secara online masih lebih rendah apabila dibandingkan dengan konsumen yang belum pernah mencoba. Dari hasil survei yang dilakukan Pradiatiningtyas (2020) kepada 100 orang responden di Jabodetabek pada bulan Juli 2020 diketahui bahwa $82 \%$ mengetahui adanya aplikasi belanja sayur online dan $18 \%$ lainnya tidak mengetahui, dan hanya $20 \%$ dari total responden yang sudah pernah berbelanja sayuran secara online, sementara $80 \%$ lainnya menyatakan belum pernah berbelanja sayuran secara online. Pelanggan memiliki kekhawatiran yang parah ketika membeli beberapa jenis produk melalui bahan makanan online, seperti daging, buah-buahan, sayuran, dan barang-barang segar lainnya (Karel et al. 2005).

Mengacu kepada hal yang melatarbelakangi itu, perumusan permasalahan dalam kegiatan meneliti ini mencakup: (1) Bagaimana perilaku pembelian sayuran melalui platform e-commerce di Jabodetabek; (2) Bagaimana pengaruh persepsi kemudahan penggunaan (perceived ease of use) terhadap persepsi kegunaan (perceived usefulness); (3) Bagaimana pengaruh persepsi kemudahan penggunaan (perceived ease of use), persepsi kegunaan (perceived usefulness) dan kepercayaan (trust) terhadap sikap (attitude); (4) Bagaimana pengaruh persepsi kegunaan (perceived usefulness), sikap (attitude), kepercayaan (trust) dan kepuasan (satisfaction) terhadap niat beli ulang (repurchase intention) sayuran menggunakan e-commerce; (5) Bagaimana implikasi manajerial yang dapat diterapkan perusahaan dalam meningkatkan niat beli ulang sayuran melalui e-commerce.

Tujuan dari penelitian yakni supaya: (1) Memahami tingkah laku dalam membeli sayuran dengan platform e-commerce pada wilayah Jabodetabek; (2) Menguji pengaruh persepsi kemudahan penggunaan (perceived ease of use) terhadap persepsi kegunaan (perceived usefulness); (3) Menguji pengaruh persepsi kemudahan penggunaan (perceived ease of use), persepsi kegunaan (perceived usefulness) serta kepercayaan (trust) terhadap sikap (attitude); (4) Menguji pengaruh persepsi kegunaan (perceived usefulness), sikap (attitude), kepercayaan (trust) dan kepuasan (satisfaction) terhadap niat beli ulang (repurchase intention) sayuran menggunakan e-commerce; (5) Melakukan perumusan dampak manajerian yang bisa diimplementasikan industri guna peningkatan niat pembelian kembali sayuran melalui e-commerce.

Penelitian ini dilakukan untuk mengembangkan Technology Acceptance Model (TAM) dimana berbagai studi sebelumnya sekadar terfokus kepada penerimaan model teknologi e-commerce mobile (Rachbini et al. 2019), mobile banking (Kurniawan et al. 2013), e-learning (Correa et al. 2015), dan information communication technology (Salman et al. 2014). Penelitian ini berupaya menambahkan konstruk kepuasan (satisfaction) sebagai variabel intervening 
dari konstruk lain yang membangun TAM yaitu variabel persepsi kegunaan (perceived usefulness), persepsi kemudahan dalam menggunakan (perceived ease of use), serta sikap (attitude) untuk melihat pengaruhnya kepada niat (intention). Penambahan konstruk lain yaitu kepercayaan (trust) pun mempunyai peranan dalam mengembangkan TAM. Hal itu bisa dinyatakan pengembangan atas suatu jumlah penelitian yang telah ada. Kegiatan meneliti ini juga berfokus pada Theory of Reasoned Action (TRA) yang merupakan dasar guna mengembangkan studi berikutnya. Penelitian dengan variabel persepsi kegunaan (perceived usefulness), persepsi kemudahan dalam menggunakan (perceived ease of use), sikap (attitude), kepercayaan (trust), kepuasan (satisfaction) serta niat pembelian ulang (repurchase intention) masih sangat terbatas khususnya untuk komoditas sayuran. Sehingga penelitian ini dilakukan untuk melengkapi berbagai penelitian di bidang niat beli ulang komoditas sayuran melalui e-commerce. Kegiatan meneliti berikut diinginkan bisa jadi masukan kepada pemilik bisnis e-commerce yang memasarkan sayuran dengan menggunakan teknologi sebagai pertimbangan dalam menetapkan peraturan strategi marketing yang efisien serta efektif. Penelitian ini juga bermafaat bagi dunia pendidikan sebagai patokan atau pedoman untuk dapat memahami beragam faktor yang memberi pengaruh niat pembelian ulang pelanggan serta sebagai bahan pustaka untuk penelitian selanjutnya.

\section{METODE PENELITIAN}

Penelitian dilaksanakan bulan Maret 2021 s/d Mei 2021. Pengumpulan data kuesioner dilakukan dari Maret sampai April 2021 kemudian dilakukan pengolahan data s/d Mei 2021. Pendekatan penelitian ini adalah penelitian kuantitatif. Penggunaan data pada kegiatan meneliti ini yakni data sekunder serta data primer. Data primer diperoleh dengan penyebaran kuesioner secara daring dengan bantuan Google Form. Sedangkan, data sekundernya didapatkan dengan data studi literatur terkait penelitian. Penyebaran kuesioner secara daring dilakukan dengan pertimbangan adanya pandemi Covid-19 sehingga tidak memungkinkan peneliti melaksankaan penyebaran kuesiner dengan bertatap muka atau langsung (face to face) kepada responden.

Teknik dalam mengambil sampel yang dilaksankaan yakni melalui non-probability sampling dengan teknik convenience sampling, dengan syarat sudah pernah berbelanja sayuran melalui e-commerce dengan satu penjual (individual seller). Teknik convenience sampling diambil karena total populasinya pada kegiatan meneliti ini tidak diidentifikasi dengan pasti serta waktu pengumpulan data yang sempit. Setiap estimasi parameter variabel endogen dan eksogen membutuhkan jumlah sampel sebanyak lima hingga sepuluh observasi (Hair et al. 2012). Dalam penelitian ini menggunakan 153 orang responden. Menurut Suharjo dan Suwarno (2002), jumlah sampel 100-200 sudah responden sudah cukup stabil dalam pendugaan. Skala pengukuran dalam kuesioner menggunakan skala likert. Uji kevaliditasan alat ukur mempergunakan product moment, serta uji reliabilitas kuesioner mempergunakan Cronbach Alpha.

Nilai t-tabel yang dipergunakan dalam kegiatan meneliti berikut yakni 1,96 dalam tingkatan kepercayaan 95\%. Uji validitas dan reliabilitas kuesioner ini menggunakan jumlah responden sebanyak 66 orang yang pernah berbelanja sayuran secara online menggunakan e-commerce dengan individual seller (contoh: Sayurbox, Tanihub, Tukangsayur.co, Keranjang Sayur, Brambang, Sayurbaba, Kedai Mart dll) untuk area di sekitar Jabodetabek. Tingkatan sig. yang dipergunakan dalam kegiatan meneliti ini yakni sejumlah 5\% sehingga diperoleh nilai $\mathrm{df}=\mathrm{n}-2$ dimana $\mathrm{n}=66$ sehingga didapatkan $\mathrm{df}=64$ dan nilai r-tabel 0,242.

Untuk menjaga kebenaran dari penelitian ini serta dapat diulang kembali oleh peneliti lainnya, maka dilakukan pencatatan hasil kuesioner sebagai data mentah untuk analisis selanjutnya. Data yang dikumpulkan diolah melalui proses cleaning dan analyzing serta interpretasi data atau membuat penafsiran dari hasil penelitian. Saat mengolah data mempergunakan microsoft Excel serta menganalisis data dilaksanakan mempergunakan Structural Equation Model (SEM) dengan perangkat lunak LISREL versi 8.7. Evaluasi atau penilaian model dilaksanakan dengan menyelenggarakan penilaian kepada model pengukurannya maupun model struktural.

\section{Hubungan Antara Persepsi Kemudahan (Perceived Ease of Use) Penggunaan Terhadap Persepsi Kegunaan (Perceived Usefulness)}

Kemudahan saat mempergunakan teknologi diduga membawa pengaruh positif terhadap persepsi kegunaan. Hal ini disebabkan bahwa jika suatu teknologi mudah digunakan dan tidak rumit, maka akan memberikan 
manfaat bagi penggunanya, misalnya dalam meningkatkan efisisensi dan produktivitas. Berdasarkan kegiatan meneliti yang dilaksanakan sebelumnya oleh Rachbini et al. (2019) diketahui yakni persepsi kemudahan dalam penggunaan (perceived ease of use) berpengaruh positif secara signifikan terhadap persepsi kegunaan (perceived usefulness). Maka dari itu, persepsi kemudahan penggunaan membawa pengaruh yang positif kepada persepsi kegunaannya dalam menggunakan e-commerce sayuran. Merujuk pada penjelasan dan teori di atas maka dapat dirumuskan hipotesis yakni:

H1: Persepsi kemudahan penggunaan (perceived ease of use) berpengaruh terhadap persepsi kegunaan (perceived usefulness).

\section{Hubungan Antara Persepsi Kemudahan Penggunaan (Perceived Ease Of Use) Terhadap Sikap (Attitude)}

Dengan hadirnya berbagai situs online termasuk e-commerce yang tersedia menjadi motivasi bagi pengguna untuk memilih salah satu e-commerce dibandingkan e-commerce lainnya. Hal tersebut selaras terhadap berbagai studi yang sudah dilaksanakan yang mengungkapkan bahwasanya jika pengguna merasakan suatu situs daring lebih sukar dipakai, tidak bisa menjumpai produk yang diinginkannya, ataupun tidak paham terkait hal yang disajikan dalam situs daring itu, pengguna bisa meninggalkan situs daring itu (Pearson et al. 2007 dalam Lee et al. 2011). Sehingga, jika pelanggan mempunyai anggapan suatu situs daring ada kemudahan dalam penggunaannya, hal itu bisa memberi pengaruh intensitasnya untuk melakukan pembelian ulang (Lee et al. 2011). Hubungan antara persepsi kemudahan penggunaan (perceived ease of use) dan sikap terhadap penggunaan teknologi (attitude toward technology use) dalam teori TAM yang diungkapkan oleh Davis (1989) dengan empiris sudah dilakukan verifikasi pada bahan bacaan teknologi informasi (Suki dan Suki 2011).

H1: Persepsi kemudahan penggunaan (perceived ease of use) berpengaruh terhadap sikap (attitude).

\section{Hubungan Antara Persepsi Kegunaan (Perceived Usefulness) Terhadap Sikap (Attitude)}

Penelitian dengan hasil persepsi kegunaan memberi pengaruhnya yang signifikan serta positif terhadap sikap seseorang saat mempergunakan teknologi sistem informasi diantaranya dikemukakan oleh Malhotra et al.
1999; Pikkarainen et al. 2004; Govindaraju dan Indriany 2007. Sementara penelitian dengan hasil persepsi kegunaan tidak membawa pengaruh terhadap sikap saat mempergunakan teknologi informasi dikemukakan oleh Taylor dan Todd (1995), Kusuma dan Susilowati (2007) dan penelitiannya Laily (2011). Merujuk pada teori diatas maka dirumuskan hipotesisnya yakni:

H1: Persepsi kegunaan (perceived usefulness) berpengaruh terhadap sikap (attitude).

\section{Hubungan Antara Persepsi Kegunaan (Perceived Usefulness) Terhadap Niat Beli Ulang (Repurchase Intention)}

Persepsi kegunaan (perceived usefulness) didefinisikan merupakan suatu ukuran terhadap kemampuan teknologi dalam menciptakan suatu manfaat untuk pihak yang menggunakannya. Penilaian positif kepada faktor persepsi manfaat diasumsikan bisa memberi pergerakan pada niat pengguna untuk mempergunakan teknologi. Berdasarkan hasil penelitian Nangi dan Sukaatmadja (2015) diketahui yakni kemudahan penggunaan, kegunaan, serta keyakinan dengan bersimultan membawa pengaruh terhadap niat beliulang (repurchase intention) mempergunakan e-commerce bagi mahasiswa program reguler Fakultas Ekonomi dan Bisnis Universitas Udayana. Berbeda dengan hasil penelitian sebelumnya, penelitian yang dilaksanakan oleh Rakhmawati dan Isharijadi (2013) menandakan hasilnya yakni persepsi kebermanfaatan tidak membawa pengaruh terhadap niat untuk menggunakan sistem internet banking. Merujuk pada teori itu sehingga ada perumusan hipotesisnya yakni:

H1: Persepsi kegunaan (perceived usefulness) berpengaruh terhadap niat beli ulang (repurchase intention).

\section{Hubungan Antara Sikap (Attitude) Terhadap Niat Beli Ulang (Repurchase Intention)}

Pada kaitan mengenai sistem informasi, sikap bisa ditampilkan melalui keyakinan individu yakni sistem informasi yang digunakannya memiliki keterampilan lebih baik, efisien, serta manfaat yang beragam. Berdasarkan penelitian yang telah dilakukan oleh Fakhrunnisa et al. (2013) didapatkan hasilnya yaitu terdapat pengaruh yang bersignifikan diantara variabel sikap pengguna internetkepadaniatperilaku (behavioral intention) mempergunakan internet. Hal itu selaras terhadap kegiatan meneliti yang mengungkapkan terdapat relasi yang positif diantara niat perilaku atau 
tingkah laku dan sikap pada kaitan menggunakan teknologi informasi (Malhotra et al. 1999). Sementara itu hasil berbeda dikemukakan oleh Taylor dan Todd (1995) serta Elok Irianing Tyas dan Darma (2017) yang mengungkapkan yakni sikap tidak mempunyai pengaruh terhadap niat tingkah laku bagi kedua grup penggunanya, baik grup yang mempunyai pengalaman dan juga yang tidak mempunyai pengalaman. Merujuk pada teori diatas dan hasil penelitian yang berbedabeda maka dirumuskan hipotesis sebagai berikut:

H1: Sikap (attitude) berpengaruh terhadap niat beli ulang (repurchase intention).

\section{Hubungan Antara Kepercayaan (Trust) Terhadap Sikap (Attitude)}

Kepercayaan pada konteks pembelian melalui daring adalah sikap sedia pelanggan yang tergantung kepada pihak lainnya serta kerentanan kepada perbuatan pihak lain saat proses pembelanjaan melalui daring atau online, yang berharap yaitu pihak lainnya akan melaksanakan praktik yang bisa diterima serta bisa memberi layanan maupun produk sesuai perjanjiannya (Zendehdel et al. 2011). Berdasarkan penelitian-penelitian sebelumnya, banyak didapatkan hasil bahwa kepercayaan (trust) berpengaruh terhadap perilaku konsumen. Kepercayaan (trust) mempunyai peranan yang berhubungan pada tingkah laku konsumen, dalam luring dang juga daring (Chen et al. 2009). Kepercayaan yang rendah sudah ada pengakuan merupakan suatu alasan dasar bagi konsumen agar tidak melaksanakan aktivitas membeli dalam toko daring (Jarvenpaa et al. 2000).

H1: Kepercayaan (trust) berpengaruh terhadap sikap (attitude)

\section{Hubungan Antara Kepercayaan (Trust) Terhadap Niat Beli Ulang (Repurchase Intention)}

Wu et al. (2010) menyatakan yakni variabel relative advantage, trust and perceived ease of use dirasa begitu penting dan membawa pengaruhnya dengan positif kepada niat konsumen dalam mempergunakan sistem online banking. Berdasarkan kegiatan meneliti yang dilaksanakan Putri et al. (2019) menyatakan bahwa variabel trust membawa pengaruhnya secara positif, namun tidak signifikan terhadap niat beli yang berulang (repurchase intention). Merujuk pada hasil kajian pustaka di atas maka dirumuskan hipotesis sebagai berikut:

H1: Kepercayaan (trust) berpengaruh terhadap niat beli ulang (repurchase intention)

\section{Hubungan Antara Sikap (Attitude) Terhadap Kepuasan (Satisfaction)}

Lee (2009) mengungkapkan yakni sikap (attitude) berpacu kepada persepsi seseorang tersebut, baik membawa untuk ataupun tidak membawa untuk kepada suatu tingkah laku. Apabila konsumen memiliki sikap yang baik pada suatu produk serta memiliki perasaan yang positif, maka diduga kepuasan konsumen pun menjadi lebih tinggi.

H1: Sikap (aattitude) berpengaruh terhadap kepuasan (satisfaction)

\section{Hubungan Antara Kepuasan (Satisfaction) Terhadap Niat Beli Ulang (Repurchase Intention)}

Hellier et al. (2003) pada penelitian yang dilaksanakannya mengungkapkan yakni kepuasan konsumen mempunyai pengaruhnya yang positif dengan langsung terhadap niat pembelian kembali. Kegiatan meneliti yang dilaksanakan oleh Fang et al. (2011) pun mengungkapkan bahwa variabel kepuasan pelanggan berpengaruh langsung terhadap niat pembelian ulang. Hal ini berarti yakni makin tinggi tingkatan kepuasannya, bermakna makin menaik niatan pembelian ulang.

H1: Kepuasan (satisfaction) berpengaruh terhadap niat beli ulang (repurchase intention).

Penelitian ini mencakup pada persepsi kegunaan (perceived usefulness), persepsi kemudahan penggunaan (perceived ease of use), sikap (attitudes), kepercayaan (trust), kepuasan (satisfaction) dan niat beli ulang (repurchase intention). Konsumen yang menjadi responden kegiatan meneliti ini ada batasan pada pelanggan yang berpengalaman melaksanakan pembelian sayuran secara online menggunakan e-commerce dengan satu penjual saja (individual seller). Berdasarkan uraian di atas, penelitian ini berupaya melakukan pembuktian berbagai hipotesis yang dirangkum pada model kerangka pemikiran sesuai Gambar 1. 


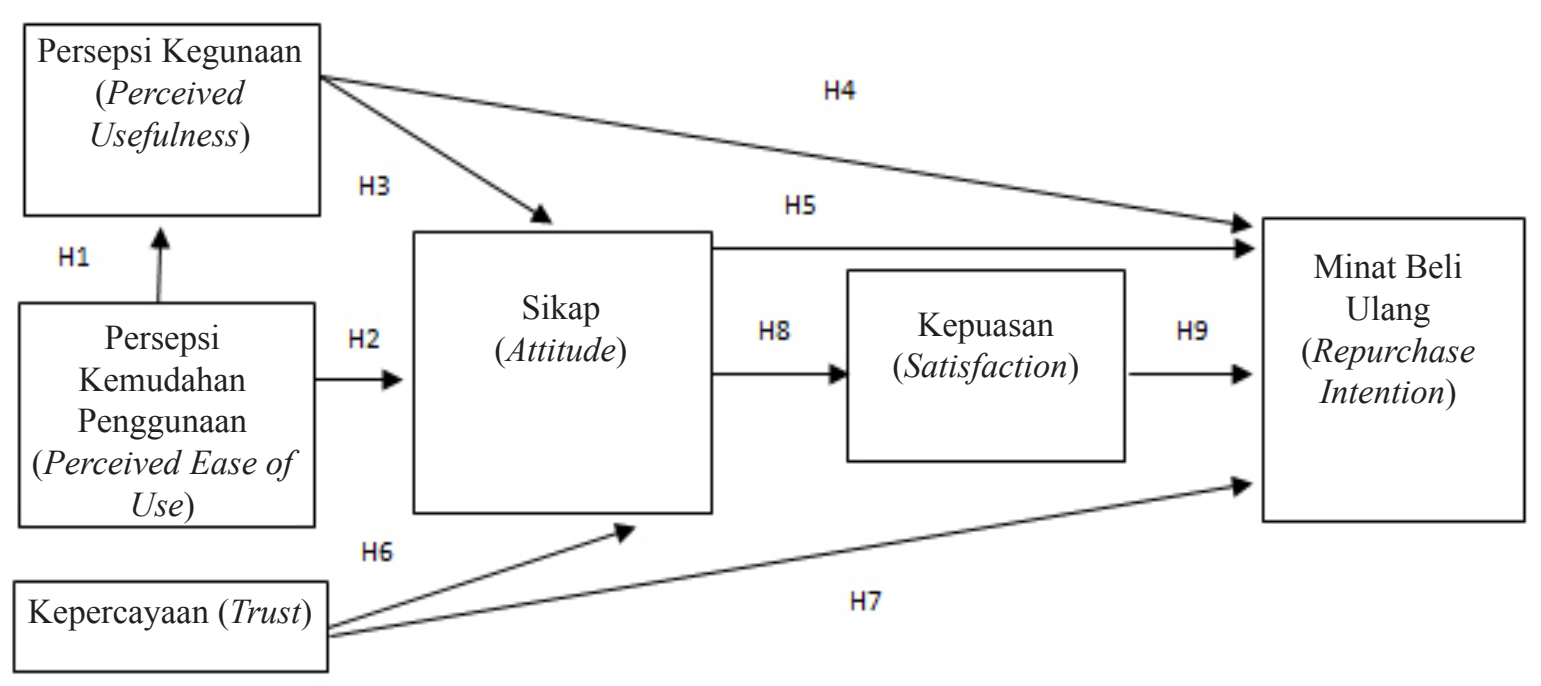

Gambar 1. Kerangka pemikiran penelitian

\section{HASIL}

\section{Karakteristik Konsumen}

Dari 153 responden didominasi oleh generasi milenial (gen Y) dan berada pada rentang usia 27 - 40 tahun sebesar 69,28 persen, jenis kelamin perempuan sebesar 73,86 persen, status perkawinan sudah menikah sebesar 75,82 persen, tingkat pendidikan mayoritas strata 1 sebesar 55,56 persen, pekerjaan responden didominasi oleh karyawan swasta sebesar 22,22 persen dan tingkat penghasilan didominasi oleh responden dengan dengan penghasilan $>\operatorname{Rp} 7-14$ juta sebesar 33,99 persen. Perilaku belanja sayuran melalui e-commerce hanya sebanyak satu hingga dua kali dalam satu bulan. Dari hasil tersebut dapat diketahui bahwa berbelanja sayuran secara online melalui e-commerce masih dalam tahap pengenalan.

\section{Analisis Model Structural Equation Modelling LISREL}

\section{Evaluasi Outer Model}

Evaluasi outer model mempunyai tujuan guna mengevaluasi kevaliditasan serta reliabilitas modelnya. Menganalisis outer model memberi gambaran relasi antar variabel laten terhadap berbagai indikator, serta bisa menjelaskan bagaimana setiap indikator berkorelasi terhadap variabel latennya (Rachmawati, 2020). Pengujian yang dilaksanakan kepada evaluasi outer model antara lain adalah convergent validity, average varian extracted (AVE) dan construct reliability (CR).

\section{Convergent Validity}

Menurut Wijanto (2008) variabel teramati dinyatakan mempunyai kevaliditasan yang baik apabila memiliki T-value $\geq 1,96$ atau praktisnya $\geq 2$, serta Standardized Loading Factor (SLF) $>0,70$. Dalam kegiatan meneliti berikut nilai loading factor yang dipergunakan yakni $>$ 0,7. Hasilnya atas uji tahapan awal ada lima indikator variabel yang bernilai loading factor kurang dari 0,7 yaitu PU1 $(0,48)$, T1 $(0,69)$, A5 $(0,7)$, A6 $(0,56)$, RI4 $(0,48)$ sehingga harus dihilangkan dan dilakukan pengujian ulang. Sesudah dilaksanakan uji ulang berarti semua indikatornya mempunyai nilai loading factor $>0,7$ sehingga telah memenuhi model convergent validity.

\section{Uji Reliabilitas}

Pengujian reliabilitas dipergunakan dalam menilai kehandalan dan konsistensinya indikator yang diukur mewakili konstruk laten. Penilaian reliabilitas melibatkan dua pengukuran yaitu Average Variance Extract (AVE) dan Construct Reliability (CR). Nilai Average Varian Extracted (AVE) harus $\geq 0,5$. Sementara menurut Hilton dan Brownlow (2004), nilai $\mathrm{CR} \geq 0,90$ menunjukkan excellent reliability, 0,70-0,9 menunjukkan high reliability, 0,5 - 0,7 menunjukkan moderate reliability dan $<0,5$ menunjukkan low reliability. Sehingga, nilainya CR yang dipergunakan $>$ 0,7 . Nilainya atas pengujian reliabilitas pada kegiatan meneliti berikut ditampilkan dalam Tabel 1. 
Tabel 1. Hasil Uji Reliabilitas

\begin{tabular}{lcccc}
\hline \multirow{2}{*}{ Variabel laten } & \multirow{2}{*}{ Variabel indikator } & \multicolumn{2}{c}{ Uji Reliabilitas } & \multirow{2}{*}{ Keterangan } \\
\cline { 3 - 4 } & & VE $\geq 0.5$ & CR $\geq 0.7$ & \\
\hline Perceived ease of use & PEU1-PEU3 & 0.609 & 0.824 & Reliable \\
Perceived usefulness & PU2-PU4 & 0.626 & 0.833 & Reliable \\
Trust & T2-T6 & 0.657 & 0.904 & Reliable \\
Attitude & A1-A4 & 0.609 & 0.862 & Reliable \\
Satisfaction & S1-S3 & 0.629 & 0.836 & Reliable \\
Repurchase intention & RI1-RI3 & 0.677 & 0.862 & Reliable \\
\hline
\end{tabular}

\section{Analisis Inner Model (Model Struktural)}

Menganalisis inner model atau model struktural yang mempunyai tujuan guna melaksanakan analisis tingkatan perkiraan antarvariabel independen kepada variabel dependennya. Nilai R-square menunjukkan tingkat determinasi variabel eksogen terhadap endogennya. Berdasarkan pengolahan data, didapatkan hasil R-square seperti yang ditampilkan pada Tabel 2 serta kontribusi indikator terhadap variabel laten ditampilkan pada Tabel 3.

\section{Kontribusi Indikator terhadap Variabel Laten}

Variabel perceived ease of use dibangun atas tiga indikator. Indikator tersebut yaitu cara berbelanja melalui e-commerce mudah dimengerti (PEU1), berbelanja sayuran secara online hanya membutuhkan sedikit usaha atau less effort (PEU2), dan kemudahan untuk terampil menggunakan aplikasi e-commerce (PEU3). Indikator yang paling mencerminkan perceived ease of use adalah responden merasa bahwa berbelanja sayuran secara online hanya membutuhkan sedikit usaha atau less effort (PEU2) yang bernilai loading factor sejumlah 0.81 serta t-hitung sejumlah 10.46.

Variabel perceived usefulness dibangun atas tiga indikator. Indikator tersebut yaitu harga sayuran yang dijual melalui e-commerce cukup kompetitif dibandingkan yang dijual secara konvensional di pasar atau supermarket (PU2), e-commerce membantu menghemat waktu untuk berbelanja sayuran (PU3) dan berbelanja menggunakan e-commerce memiliki fleksibilitas tinggi sehingga membantu responden lebih produktif mengerjakan hal lainnya (PU4). Indikator yang paling mencerminkan perceived usefulness adalah e-commerce membantu menghemat waktu untuk berbelanja sayuran (PU3) yang bernilai loading factor sejumlah 0,81 serta t-hitung sejumlah 9,66.

Variabel trust dibangun atas lima indikator. Indikator tersebut yaitu e-commerce sayuran pilihan saya memiliki pengalaman bisnis yang baik di bidangnya (T2), memiliki kemauan untuk memberikan keuntungan bagi pelanggan (T3), dapat memberikan solusi terbaik atas keluhan konsumen (T4), selalu memenuhi harapan pelanggan (T5) dan dapat dipercaya (T6). Indikator yang paling mencerminkan trust adalah e-commerce dipercaya selalu memenuhi harapan pelanggan (T5) yang bernilai loading factor sejumlah 0,86 serta t-hitung sejumlah 13,09.

Variabel attitude dibangun atas empat indikator. Indikator tersebut yaitu sayuran yang dijual melalui e-commerce lebih terjamin kualitasnya (A1), layanan berbelanja sayuran melalui e-commerce lebih baik dibandingkan cara berbelanja konvensional (A2), saya suka memanfaatkan teknologi informasi untuk berbelanja sayuran secara online melalui e-commerce (A3), memanfaatkan teknologi untuk berbelanja sayuran sangat nyaman dan menyenangkan (A4). Indikator yang paling mencerminkan attitude adalah sayuran yang dijual melalui e-commerce lebih terjamin kualitasnya (A1) dengan nilai loading factor sebesar 0,84 .

Tabel 2, Nilai R-square Hasil SEM

\begin{tabular}{lc}
\hline Variabel Laten & Nilai R-Square \\
\hline Perceived usefulness & 0,64 \\
Attitude & 0,85 \\
Satisfaction & 0,82 \\
Repurchase intention & 0,81 \\
\hline
\end{tabular}


Tabel 3. Kontribusi indikator

\begin{tabular}{|c|c|c|c|c|c|}
\hline Konstruk & Kode & Indikator & $\begin{array}{l}\text { Loading } \\
\text { factor }\end{array}$ & T-hitung & Ket \\
\hline \multirow{3}{*}{$\begin{array}{l}\text { Perceived ease } \\
\text { of use }\end{array}$} & PEU1 & Cara berbelanja melalui e-commerce mudah dimengerti & 0,80 & $10,16^{*}$ & Valid \\
\hline & PEU2 & $\begin{array}{l}\text { Berbelanja sayuran secara online hanya membutuhkan } \\
\text { sedikit usaha (less effort) }\end{array}$ & 0,81 & $10,46^{*}$ & Valid \\
\hline & PEU3 & $\begin{array}{l}\text { Mudah bagi saya untuk terampil menggunakan aplikasi } \\
\text { e-commerce }\end{array}$ & 0,72 & $8,80^{*}$ & Valid \\
\hline \multirow[t]{3}{*}{$\begin{array}{l}\text { Perceived } \\
\text { usefulness }\end{array}$} & PU2 & $\begin{array}{l}\text { Harga sayuran yang dijual melalui e-commerce cukup } \\
\text { kompetitif dibandingkan yang dijual secara konvensional } \\
\text { di pasar atau supermarket }\end{array}$ & 0,75 & & Valid \\
\hline & PU3 & $\begin{array}{l}\text { E-commerce membantu saya menghemat waktu untuk } \\
\text { berbelanja sayuran }\end{array}$ & 0,81 & $9,66^{*}$ & Valid \\
\hline & PU4 & $\begin{array}{l}\text { Berbelanja menggunakan e-commerce memiliki } \\
\text { fleksibilitas tinggi sehingga membantu saya untuk bisa } \\
\text { lebih produktif mengerjakan hal lainnya }\end{array}$ & 0,80 & $9,56^{*}$ & Valid \\
\hline \multirow[t]{5}{*}{ Trust } & $\mathrm{T} 2$ & $\begin{array}{l}\text { E-commerce sayuran pilihan saya memiliki pengalaman } \\
\text { bisnis yang baik di bidangnya }\end{array}$ & 0,76 & $10,86^{*}$ & Valid \\
\hline & $\mathrm{T} 3$ & $\begin{array}{l}\text { Saya percaya e-commerce sayuran pilihan saya memiliki } \\
\text { kemauan untuk memberikan keuntungan bagi pelanggan }\end{array}$ & 0,80 & $11,64^{*}$ & Valid \\
\hline & $\mathrm{T} 4$ & $\begin{array}{l}\text { Saya percaya e-commerce sayuran pilihan saya dapat } \\
\text { memberikan solusi terbaik atas keluhan konsumen }\end{array}$ & 0,82 & $12,02 *$ & Valid \\
\hline & T5 & $\begin{array}{l}\text { Saya percaya e-commerce sayuran pilihan saya selalu } \\
\text { memenuhi harapan pelanggan }\end{array}$ & 0,86 & $13,09 *$ & Valid \\
\hline & T6 & $\begin{array}{l}\text { Saya percaya e-commerce sayuran pilihan saya dapat } \\
\text { dipercaya }\end{array}$ & 0,79 & $11,56^{*}$ & Valid \\
\hline \multirow[t]{4}{*}{ Attitude } & A1 & $\begin{array}{l}\text { Sayuran yang dijual melalui e-commerce lebih terjamin } \\
\text { kualitasnya }\end{array}$ & 0,84 & & Valid \\
\hline & $\mathrm{A} 2$ & $\begin{array}{l}\text { Layanan berbelanja sayuran melalui e-commerce lebih } \\
\text { baik dibandingkan cara berbelanja konvensional }\end{array}$ & 0,76 & $11,99 *$ & Valid \\
\hline & $\mathrm{A} 3$ & $\begin{array}{l}\text { Saya suka memanfaatkan teknologi informasi untuk } \\
\text { berbelanja sayuran secara online melalui e-commerce }\end{array}$ & 0,75 & $10,53^{*}$ & Valid \\
\hline & A4 & $\begin{array}{l}\text { Memanfaatkan teknologi untuk berbelanja sayuran } \\
\text { sangat nyaman dan menyenangkan }\end{array}$ & 0,76 & $10,75^{*}$ & Valid \\
\hline \multirow[t]{3}{*}{ Satisfaction } & S1 & $\begin{array}{l}\text { Saya puas dengan kesegaran produk yang dijual di } \\
\text { e-commerce sayuran }\end{array}$ & 0,77 & & Valid \\
\hline & S2 & $\begin{array}{l}\text { Saya puas dengan layanan yang diberikan oleh } \\
\text { e-commerce sayuran }\end{array}$ & 0,79 & $12,00 *$ & Valid \\
\hline & S3 & $\begin{array}{l}\text { E-commerce sayuran yang saya gunakan telah mampu } \\
\text { memenuhi harapan saya }\end{array}$ & 0,80 & $9,96^{*}$ & Valid \\
\hline \multirow[t]{3}{*}{$\begin{array}{l}\text { Repurchase } \\
\text { intention }\end{array}$} & RI1 & $\begin{array}{l}\text { Saya tertarik untuk melakukan pembelian ulang } \\
\text { komoditas sayuran melalui e-commerce }\end{array}$ & 0,87 & & Valid \\
\hline & RI2 & $\begin{array}{l}\text { Saya akan merekomendasikan e-commerce sayuran } \\
\text { pilihan saya kepada orang lain }\end{array}$ & 0,86 & $13,28^{*}$ & Valid \\
\hline & RI3 & $\begin{array}{l}\text { Saya lebih menyukai membeli sayuran melalui } \\
\text { e-commerce dibandingkan harus berbelanja langsung ke } \\
\text { pasar atau supermarket }\end{array}$ & 0,75 & $10,98^{*}$ & Valid \\
\hline
\end{tabular}


Variabel satisfaction dibangun atas tiga indikator. Indikator tersebut yaitu saya puas dengan kesegaran produk yang dijual di e-commerce sayuran (S1), saya puas dengan layanan yang diberikan oleh e-commerce sayuran (S2), e-commerce sayuran yang saya gunakan telah mampu memenuhi harapan saya (S3). Indikator yang paling mencerminkan satisfaction adalah e-commerce sayuran yang saya gunakan telah mampu memenuhi harapan saya (S3) yang bernilai loading factor sejumlah 0,80 serta t-hitung sejumlah 9,96.

Variabel repurchase intention dibangun atas tiga indikator. Indikator tersebut yaitu saya tertarik untuk melakukan pembelian ulang komoditas sayuran melalui e-commerce (RI1), saya akan merekomendasikan e-commerce sayuran pilihan saya kepada orang lain (RI2), dan saya lebih menyukai membeli sayuran melalui e-commerce dibandingkan harus berbelanja langsung ke pasar atau supermarket (RI3). Indikator yang paling mencerminkan repurchase intention adalah saya tertarik untuk melakukan pembelian ulang komoditas sayuran melalui e-commerce (RI1) dengan nilai loading factor sebesar 0,87 .

\section{Pengujian Hipotesis}

Uji hipotesisnya dalam kegiatan meneliti ini dilaksanakan melalui analisis nilai koefisien jalur serta nilai t-hitung atas model strukturalnya. Variabel dianggap berpengaruh signifikan jika t-hitung $\geq 1.96$. Keragaman faktor turut diukur melalui $\mathrm{R}$-square. Hasil dari uji hipotesis yang didapatkan pada kegiatan meneliti berikut ditampilkan dalam Tabel 4.

Perceived ease of use membawa pengaruh positif serta bersignifikan terhadap perceived usefulness yang bernilai koefisien jalur sebesar 0,22 dan t-hitung sebesar 2,37. Hal ini menunjukkan bahwa makin besar perceived ease of use berarti perceived usefulness pun bisa semakin besar. Hasil atas kegiatan meneliti berikut ditunjang dari penelitian yang dilaksanakan Tyas dan Darma (2017) yang mengungkapkan persepsi kemudahan saat menggunakan (perceived ease of use) suatu sistem membawa pengaruh yang positif dengan bersignifikan terhadap persepsi kegunaan (perceived usefulness).

Perceived ease of use tidak bersignifikan kepada attitude secara langsung. Hasil berikut tidak selaras terhadap penelitiannya Law et al. (2016) yang mengungkapkan perceived ease of use membawa pengaruh yang positif serta bersignifikan terhadap sikap. Akan tetapi hasil atas kegiatan meneliti ini bisa berkonsisten terhadap teori TAM yakni ada relasi diantara perceived ease of use dan attitude toward technology use (BurtonJones dan Hubona 2005) meskipun tidak signifikan. Perceived ease of use berpengaruh terhadap attitude dapat melalui perceived usefulness.

Perceived usefulness membawa pengaruh yang positif dan bersignifikan terhadap attitude yang bernilai koefisien jalur sejumlah 0,21 serta t-hitung sejumlah 2,30. Hal ini sejalan dengan hasil penelitian yang dilaksanakan oleh Thuy et al. (2015) yang mengungkapkan yakni perceived usefulness membawa pengaruh yang positif dan bersignifikan terhadap attitude. Sehingga semakin besar persepsi manfaat yang dirasakan terhadap e-commerce sayuran maka akan semakin meningkatkan sikap positif konsumen.

Perceived usefulness membawa pengaruh yang positif namun tidak bersignifikan terhadap repurchase intention. Hal tersebut tidak selaras terhadap hasil kegiatan meneliti yang sebelumnya yang menyatakan yakni perceived usefulness membawa pengaruh yang positif dan bersignifikn terhadap repurchase intention (Rahman et al. 2020). Hasil dalam penelitian ini selaras terhadap penelitiannya Rakhmawati dan Isharijadi (2013) bahwasanya persepsi kebermanfaatan tidak ada pengaruhnya terhadap niat penggunaan sistem internet banking. Perceived usefulness membawa pengaruh kepada repurchase intention bisa dengan sikap dan kepuasan. Dikarenakan perceived usefulness ada pengaruh yang nyata kepada sikap, sikap membawa pengaruh nyata kepada kepuasan, serta kepuasan membawa pengaruh yang nyata terhadap repurchase intention.

Attitude berpengaruh positif tetapi tidak signifikan terhadap repurchase intention. Hasil ini tidak sejalan dengan penelitian sebelumnya yang menyatakan bahwa attitude berpengaruh positif dan signifikan terhadap repurchase intention (Kim dan Chung 2011). Hasil dalam penelitian ini sejalan dengan yang dilakukan oleh Taylor dan Todd (1995) serta Elok Irianing Tyas dan Darma (2017) yang menyebutkan bahwa sikap tidak memiliki pengaruh terhadap niat perilaku. Attitude berpengaruh signifikan terhadap repurchase intention dapat melalui satisfaction. Hal ini disebabkan karena attitude berpengaruh positif sigifikan terhadap satisfaction begitupun satisfaction berpengaruh positif signifikan terhadap repurchase intention. 
Tabel 4. Hasil uji hipotesis

\begin{tabular}{lccl}
\hline \multicolumn{1}{c}{ Path } & Koefisien Jalur & T-hit $\geq 1,96$ & \multicolumn{1}{c}{ Kesimpulan } \\
\hline Perceived ease of use $\rightarrow$ Perceived usefulnes & 0,22 & $2,37^{*}$ & Signifikan (Terima H1) \\
Perceived ease of use $\rightarrow$ Attitude & 0,10 & 1,68 & Tidak Signifikan (Tolak H1) \\
Perceived usefulnes $\rightarrow$ Attitude & 0,21 & $2,30^{*}$ & Signifikan (Terima H1) \\
Perceived usefulnes $\rightarrow$ Repurchase intention & 0,07 & 0,513 & Tidak Signifikan (Tolak H1) \\
Attitude $\rightarrow$ Repurchase intention & 0,11 & 0,394 & Tidak Signifikan (Tolak H1) \\
Trust $\rightarrow$ Attitude & 0,68 & $6,919^{*}$ & Signifikan (Terima H1) \\
Trust $\rightarrow$ Repurchase intention & $-0,17$ & $-0,689$ & Tidak Signifikan (Tolak H1) \\
Attitude $\rightarrow$ Satisfaction & 1,00 & $9,968^{*}$ & Signifikan (Terima H1) \\
Satisfaction $\rightarrow$ Repurchase intention & 0,90 & $2,189^{*}$ & Signifikan (Terima H1) \\
\hline
\end{tabular}

Keterangan: *) Signifikan pada t-hitung $\geq 1.96$

Trust berpengaruh positif dan signifikan terhadap attitude dengan nilai koefisien jalur sebesar 0,60 dan t-hitung sebesar 6,92. Hasil ini sejalan dengan penelitian sebelumnya yang menyatakan bahwa trust berpengaruh positif signifikan terhadap attitude (Putra et al. 2017). Artinya seseorang akan cenderung memiliki sikap positif jika memiliki kepercayaan yang tinggi terhadap e-commerce sayuran yang digunakannya.

Trust berpengaruh tidak signifikan terhadap repurchase intention. Hasil ini tidak sejalan dengan penelitian sebelumnya yang menyatakan bahwa trust berpengaruh positifsignifikan terhadap repurchase intention (Pratiwi, 2016). Dalam hasil penelitian ini, trust berpengaruh terhadap repurchase intention secara tidak langsung melalui perceived usefulness, attitude dan satisfaction.

Attitude berpengaruh positif dan signifikan terhadap satisfaction dengan nilai koefisien jalur sebesar 1,01 dan t-hitung sebesar 9,97. Hasil ini sesuai pernyataan Lee (2009) bahwa sikap (attitude) mengacu pada persepsi individu itu sendiri, baik menguntungkan atau tidak menguntungkan terhadap perilaku tertentu. Apabila konsumen memiliki sikap yang baik pada suatu produk serta memiliki perasaan yang positif, maka kepuasan konsumen pun menjadi lebih tinggi.

Satisfaction berpengaruh positif signifikan terhadap repurchase intention dengan nilai koefisien jalur sebesar 0,90 dan t-hitung sebesar 2,19. Hasil ini sejalan dengan penelitian Hellier et al. 2003, Fang et al. 2011, Pastikarani dan Astuti 2016 yang menyatakan bahwa kepuasan berpengaruh positif terhadap niat beli ulang. Artinya semakin tinggi kepuasan konsumen terhadap produk maupun layanan e-commerce sayuran maka niat beli ulang juga semakin meningkat.

\section{Implikasi Manajerial}

Dari hasil penelitian yang dilakukan, dilihat dari segi demografi maka mayoritas konsumen yang berbelanja sayur online melalui e-commerce merupakan generasi $\mathrm{Y}$, berjenis kelamin perempuan dan telah berkeluarga. Sementara variabel yang membawa pengaruh positif serta bersignifikan dengan langsung kepada repurchase intention adalah satisfaction. Oleh karena itu implikasi manajerial menggunakan pendekatan 4C (co-creation, currency, communal activation, dan conversation) yang dapat diterapkan untuk mengembangkan sikap positif dan kepuasan konsumen antara lain dengan cara peningkatan layanan melalui same day delivery bagi kota satelit di sekitar Jakarta, menyediakan customer service yang handal untuk menangani keluhan konsumen dan memberikan solusi terbaik pagi permasalahan konsumen dalam berbelanja, memberikan pilihan kepada konsumen terkait preferensinya dalam pembelian sayuran terkait kuantitas atau kualitas, memberikan harga yang lebih kompetitif dibandingkan dengan harga sayuran yang dijual secara offline, pemberian diskon, voucher, free gift, maupun free shipping dengan minimum belanja yang rendah dapat berdampak langsung pada repurchase intention serta menyediakan wadah bagi konsumen untuk memberikan umpan balik (feedback) maupun memberi rekomendasi secara obyektif.

\section{KESIMPULAN DAN SARAN}

\section{Kesimpulan}

Dalam penelitian ini didapatkan hasil bahwa yang memiliki pengaruh signifikan secara langsung terhadap sikap (attitude) adalah kepercayaan (trust). 
Sementara variabel yang memiliki pengaruh signifikan secara langsung terhadap niat beli ulang (repurchase intention) adalah kepuasan (satisfaction). Oleh karena itu implikasi manajerial yang dapat dilakukan oleh pengusaha sayuran di e-commerce untuk meningkatkan niat beli antara lain dengan terus melakukan strategi yang dapat meningkatkan kepercayaan sehingga dapat meningkatkan sikap positif dan kepuasan konsumen. Strategi pemasaran untuk membangun sistem yang dapat dipercaya yaitu dengan terus menerus melakukan penyempurnaan sistem demi kemudahan dan kenyamanan berbelanja konsumen. Sementara strategi untuk meningkatkan kepuasan melalui pengembangan sikap positif konsumen dapat dilakukan dengan cara melibatkan pelanggan dalam tahap inovasi, memberikan harga yang lebih kompetitif, memberikan diskon, voucher, free gift, maupun free shipping dengan minimum belanja yang rendah, berkolaborasi dengan komunitas dan meningkatkan conversation di sosial media.

Kebaruan atau novelty dalam penelitian ini yaitu penggabungan teoriTAMdanTRAyangdikombinasikan dengan variabel kepercayaan (trust) dan variabel intervening berupa kepuasan (satisfaction) untuk melihat pengaruhnya ke niat beli ulang (repurchase intention). Dari sisi temuan empiris dalam penelitian ini didapatkan hasil bahwa kepuasan (satisfaction) merupakan variabel intervening yg sangat penting sebagai penghubung antara variabel lainnya dengan niat beli ulang. Dari sisi implikasi manajerial yg paling baru yaitu adanya saran untuk menyelenggarakan acara kokreasi dan kolaborasi secara rutin setiap tahun, menciptakan produk custom sesuai selera konsumen, memperkuat pemasaran melalui kolaborasi dengan komunitas serta peningkatan conversation di sosial media melalui strategi pemasaran horizontal dimana konsumen berperan sebagai pengantar pesan atas keunggulan-keunggulan produk maupun layanan yang dimiliki e-commerce.

\section{Saran}

Saran untuk penelitian selanjutnya sebaiknya menambahkan variabel lain yang diperkirakan berpengaruh terhadap niat beli ulang selain variabelvariabel yang telah digunakan dalam penelitian ini, misalnya variabel perceived risk. Cakupan wilayah yang diambil dapat diperluas tidak hanya di daerah pusat konsumsi Jabodetabek. Penelitian mendatang diharapkan dapat melakukan wawancara secara langsung kepada responden dan pihak e-commerce agar mendapatkan wawasan yang lebih lengkap dan mendalam terkait niat beli ulang konsumen, kondisi yang dihadapi para pelaku usaha, serta prospek pengembangannya di era kenormalan baru (new normal).

Keterbatasan dalam penelitian ini yaitu metode penyebaran kuesioner melalui media online yaitu google form yang disebarkan melalui whatsapp maupun media sosial instagram. Kondisi ini memungkinkan adanya perbedaan persepsi antara responden dan peneliti terkait interpretasi kuesioner. Selain itu peneliti juga memiliki keterbatasan waktu pengambilan data yang relatif singkat yaitu dalam kurun waktu 1 bulan. Hal ini disebabkan pada pertengahan April 2021 mulai memasuki bulan Ramadhan, sehingga ada kekhawatiran bahwa pengambilan data di bulan tersebut kurang mencermikan pembelian aktual masyarakat dalam berbelanja sayur secara online melalui e-commerce.

\section{DAFTAR PUSTAKA}

[APJII] Asosiasi Penyelenggara Jasa Internet Indonesia. 2020. Buletin APJII Edisi 74 November 2020. https://apjii.or.id/downfile/file/ BULETINAPJIIEDISI74November2020.pdf. [03 Januari 2020].

[BKP] Badan Ketahanan Pangan. 2019. Direktori konsumsi pangan. http://bkp.pertanian. go.id/storage/app/media/PPID 2019/PRINT DIREKTORI KONSUMSI PANGAN 2019.pdf. [11 Februari 2021].

Burton-Jones A, Hubona GS. 2005. Individual differences and usage behavior: Revisiting a technology acceptance model assumption. Data Base Advances in Information Systems 36(2):5877. https://doi.org/10.1145/1066149.1066155.

Chen SC, Chen HH, Chen MF. 2009. Determinants of satisfaction and continuance intention towards self-service technologies. Industrial Management \& Data Systems 109(91248-1263). https://doi. org/10.1108/02635570911002306.

Correa R, Arenas-Gaitán J, Rondán-Cataluña FJ. 2015. Gender and acceptance of e-learning: A multi-group analysis based on a structural equation model among college students in Chile and Spain. PLoS ONE 10(10). https://doi. org/10.1371/journal.pone.0140460.

Davis FD. 1989. Perceived usefulness, perceived 
ease of use, and user acceptance of information technology. MIS Quarterly 13(3):319-340. https://doi.org/10.2307/249008.

Ditjenhorti. 2019. Rencana strategis direktorat jenderal hortikultura tahun 2020-2024. http://hortikultura. pertanian.go.id/wp-content/uploads/2020/06/ Renstra-Horti-2020-2024.pdf. [29 Januari 2021].

Fakhrunnisa A, Astuti ES, Susilo H. 2013. Pengaruh persepsi kemanfaatan dan sikap pengguna terhadap minat menggunakan internet (studi pada tenaga kependidikan di fakultas ilmu administrasi Universitas Brawijaya Malang). JurnalAdministrasi Bisnis Universitas Brawijaya 5(2):1-9.

Fang YH, Chiu CM, Wang ETG. 2011. Understanding customers satisfaction and repurchase intention an integration of IS success model, trust and justice. Internet Research 21(4):479-503.

Govindaraju R, Indriany N. 2007. Studi Mengenai Penerimaan Sistem ERP: Enhancement Terhadap Model Penerimaan Sistem ERP Berbasis Technology Acceptance Model. Dalam: 4th National Industrial Engineering Conference. pp 654-664.

Hair JF, Sarstedt M, Pieper T, Ringle CM. 2012. The use of partial least squares structural equation modeling in strategic management research: A review of past practices and recommendations for futures applications. Long Range Planning 45(5-6):320-340.

Hellier PK, Geursen GM, Carr RA, Rickard JA. 2003. Customer repurchase intention: A general structural equation model. European Journal of Marketing 37(11):1762-1800.

Iprice. 2020. Peta e-commerce Indonesia. https://iprice. go.id/insights/mapofecommerce/. [22 Februari 2021]

Jarvenpaa SL, Tractinsky N, Vitale M. 2000. Consumer trust in an internet store. Information Technology and Management 1(1-2):45-71.https://doi. org/10.1023/A:1019104520776.

Karel BK, Frohlich MT, Hult G, Tomas M. 2005. Extending The Supply Chain: How Cuttingedge Companies Bridge The Critical Last Mile into Customer's Homes. Ed. ke-1. New York: American Management Association.

Katadata. 2020a. Jumlah pengguna internet di Indonesia capai 196,7 juta. https://databoks.katadata.co.id/ datapublish/2020/11/11/jumlah-penggunainternet-di-indonesia-capai-1967-juta.
Januari 2021].

Katadata. 2020b. E-commerce tumbuh di tengah pandemi covid-19. https://katadata.co.id/ ariayudhistira/infografik/5ec48b 7 f099d1/ecommerce-tumbuh-di-tengah-pandemi-covid19. [29 Januari 2021].

Kurniawan D, Semuel H, Japarianto E. 2013. Analisis penerimaan nasabah terhadap layanan mobile banking dengan menggunakan pendekatan technology acceptance model dan theory of reasoned action. Jurnal Manajemen Pemasaran 1(1):1-13.

Kusuma H, Susilowati D. 2007. Determinan pengadopsian layanan internet banking: Perspektif konsumen perbankan Daerah Istimewa Yogyakarta. Jurnal Akuntansi dan Auditing Indonesia 11(2):125-139.

Kim HY, Chung J. 2011. Consumer purchase intention for organic personal care products. Journal of Consumer Marketing 28(1):40-47.

Laily HN. 2011. Faktor-faktor yang mempengaruhi penerimaan model software as a service terhadap sistem sales force automation pada perusahaan farmasi Indonesia [disertasi]. Depok: Universitas Gunadarma.

Law M, Kwok R, Ng M. 2016. An extended online purchase intention model for middle-aged online users. Electronics Commerce Research and Applications 20(11):132-146.https://doi. org/10.1016/j.elerap.2016.10.005.

Lee CH, Eze U, Ndubisi NO. 2011. Analyzing key determinants of online repurchase intentions. Asia Pasific Journal of Marketing and Logistics 23(2):200-221. https://doi. org/10.1108/13555851111120498.

Lee MC. 2009. Factors influencing the adoption of internet banking: an integration of TAM and TPB with perceived risk and perceived benefit. Electronic Commerce Research and Applications 8(3):130-141.https://doi.org/10.1016/j. elerap.2008.11.006.

Malhotra Y, Galetta DF. 1999. Extending the technology acceptance model to account for social influence: theoretical bases and empirical validation. In: Proceedings 32nd Hawaii International Converence on System Science. https://www. researchgate.net/publication/2859130.

$[22$ Februari 2021].

Nangi IY, Sukaatmadja IPG. 2015. Pengaruh aplikasi TAM dan kepercayaan terhadap minat mahasiswa membeli ulang menggunakan e-commerce 
dalam pembelian produk pakaian dan aksesories. E-Jurnal Manajemen Unud 4(7):1771-1784.

Pastikarani DA, Astuti SRT. 2016. Analisis pengaruh faktor-faktor minat beli ulang dengan kepuasan pelanggan sebagai variabel intervening (studi kasus pada pelanggan Hest'in Modiste di Jakarta). Diponegoro Journal of Management 5(2):1-9.

Pikkarainen T, Pikkarainen K, Karjaluoto H, Pahnila S. 2004. Costumer acceptance of online banking: an extension of the technology acceptance model. Internet Research 14(3):224-235. https://doi. org/10.1108/10662240410542652.

Pradiatiningtyas D. 2020. Preferensi dan keputusan pembelian konsumen pada aplikasi belanja online saat pandemi covid-19 (studi kasus: Go Mart dan aplikasi sayur online). Journal Speed - Sentra Penelitian Engineering dan Edukasi 12(3):51-55.

Pratiwi ED. 2016. Faktor yang mempengaruhi niat menggunakan instagram dengan the theory of reasoned action menggunakan AMOS21. Jurnal Teknik Komputer AMIK BSI 2(1):68-77.

Putra IMEW, Dantes GR, Candiasa IM. 2017. Model pengukuran tingkat kepercayaan pelanggan (online trust) terhadap situs e-commerce (studi Kasus pada pelanggan e-commerce di provinsi Bali). Journel of Natural Science and Engineering 1(3):100-109.

Putri IGAAM, Darwini S, Dakwah MM. 2019. Pengaruh trust dan easy of use terhadap minat beli ulang pada marketplace Shopee di Kota Mataram. Jurnal Rekayasa Mesin 19(1):19-32. https://doi.org/10.29303.jrm.v19i1.3.

Rachbini W, Salim F, Haque MG, Rahmawati E. 2019. Analisisniatpembelianulange-commercemobile dengan pendekatan technology acceptance model. Jurnal Aplikasi Manajemen dan Bisnis 5(3):530-540. https://doi.org/10.17358/ jabm.5.3.530.

Rachmawati ANN. 2020. Strategi Pengembangan human capital dalam meningkatkan Kinerja Perusahaan [tesis]. Bogor: Sekolah Pascasarjana, Institut Pertanian Bogor.

Rahman S, Fadrul, Yusrizal, Sudarno. 2020. Perception of e-customers for e-business: effects of covid19 on online food customer perception who buys through the e-transportation application. PalArch's Journal of Archaeology of Egypt 17(7):6836-6855.
Rakhmawati S, Isharijadi. 2013. Pengaruh kepercayaan, persepsi kegunaan, persepsi kemudahan, dan persepsi kenyamanan terhadap minat penggunaan sistem internet banking pada nasabah Bank Muamalat cabang pembantu Madiun. Jurnal Akuntansi dan Pendidikan 2(2):71-84. https:// doi.org/10.25273/jap.v2i2.1200.

Salman A, Abdullah M, Aziz J, Ahmad AL, Kee CP. 2014. Remodelling technology acceptance model in explaining user acceptence towards information and communication technology. International Journal of Arts and Sciences 7(1):159-171.

Suharjo B, Suwarno. 2002. Model Persamaan Struktural, Teori, dan Aplikasinya. Bogor: IPB Press.

Suki NM, Suki NM. 2011. Exploring the relationship between perceived usefulness, perceived ease of use, perceived enjoyment, attitude and subscriber's intention towards using $3 \mathrm{G}$ mobile services. Journal of Information Technology Management 22(1):1-7.

Taylor S, Todd PA. 1995. Understanding information technology usage: A test competing models. Information System Research 6(2):144-176. https://doi.org/10.1287/isre.6.2.144.

Thuy V, Vi D, Linh N. 2015. The impact of social presence in the web interface on customer's purchase intention toward online stores: The case of Vietnam. International Journal of Education and Social Science 2(4):7-85.

Tyas EI, Darma ES. 2017. Pengaruh perceived usefulness, perceived ease of use, perceived enjoyment, dan actual usage terhadap penerimaan teknologi informasi: studi empiris pada karyawan bagian akuntansi dan keuangan Baitul Maal Wa Tamwil wilayah Daerah Istimewa Yogyakarta dan sek. Reviu Akuntansi dan Bisnis Indonesia 1(1):25-35. https://doi.org/10.18196/ rab.01010310.18196/rab.010103.

Wu HY, Lin CC, Li O, Lin HH. 2010. A Study of bank customers' perceived usefulness of adopting online banking. Global Journal of Business Research 4(3):101-108.

Zendehdel M, Paim L, Bojei J, Osman S. 2011. The effects of trust on online Malaysian students buying behavior. Australian Journal of Basic Applied Sciences 5(12):1125-1132. 